\title{
NAGA IDENTITY POETICS IN CONTEMPORARY NAGA ENGLISH LITERATURE (A KALEIDOSCOPIC VIEW)
}

\author{
Sankar Biswas *1凶(iD) \\ ${ }^{*}{ }^{1}$ Senior Assistant Professor, Department of English, Amguri College, Amguri, India
}

DOI: https://doi.org/10.29121/granthaalayah.v8.i11.2020.2076

Article Type: Research Article

Article Citation: Sankar Biswas. (2020). NAGA IDENTITY POETICS IN CONTEMPORARY NAGA ENGLISH LITERATURE (A KALEIDOSCOPIC VIEW). International Journal of Research -GRANTHAALAYAH, 8(11), 35-40.

https://doi.org/10.29121/granthaalayah.v8.i11.2020.2076

Received Date: 16 October 2020

Accepted Date: 22 November 2020

Keywords:

Naga Identity

Contemporary

Naga English Literature

\section{ABSTRACT}

The Nagas originally a Sino-Mongoloid tribe are substantiated to have originated around 10th century B.C. in the plains between Huang Ho and Yangtze Ho in North Central China. As migration is a process which is reported to have been going on since time immemorial, the Nagas too could not have isolated themselves from being a part of the mass odyssey from their homeland with the anticipation of exploring and settling in naturally upgraded habitats. Hence today, the Nagas have been found to inhabit the banks of Chindwin and Irawaddy Rivers in Myanmar, and Nagaland in India. As far as their language is concerned, it is said to be an affiliate of the greater branch of SinoTibetan besides sharing certain similarities with Tibeto-Burman languages. As for the etymology of the word Naga is concerned, it is said to have been derived from either of the Sanskrit word namely Nagna or Nag with respective meanings 'naked' or 'mountain. Frankly speaking both the etymons in question validate the universally recognized conception of Naga identity. Nagaland itself is dotted with multiple number of hills and a faction of people among all the Naga Tribes are said to have been still embracing primitivism. But what is most conspicuous about the Nagas is that though today we know Nagaland as a self-Governing state, the fact can never be contradicted that Nagas have never considered themselves part of India despite the state being taken over by India in 1952. Right from their partially being colonized by the British in the middle of the 19th century, to their strict resistance to both the BritishIndian Government and then to the post-Independence Indian Government, the Nagas have shown that their assimilation to Indian mainstream is a daunting and cumbersome exercise. The origin of the Naga National Council, preceded by the armed resistance movement of Rani Gyindulu and that of the genesis of National Socialist Council of Nagaland simply bespeak that this prospect of wholesale assimilation into Indian Sense of Nationality will await the elapse of an elongated stretch of historical time. This very aspect has been enjoying international attention and the literary activists of Nagaland such as Dr Temsula Ao and Dr Easterine Kire have contributed a lot through their literary output in harnessing this aspect, throwing new critical insights into the same. This avouched denial cum resistance to be assimilated into the greater Indian National Fabric is one of the many facets of Naga Identity which

(C) 2020 The Author(s). This is an open access article distributed under the terms of the Creative Commons Attribution License, which permits unrestricted use, distribution, and reproduction in any medium, provided the original author and source are credited. 
also encompasses other cultural traits such as patriarchal ideology, Naga Heraka Practices, Animism, Mythogenesis and Head-Hunting Practices.

Objective of this write-up: This write-up endeavours its best to foreground the very traits of Naga Identity Poetics by taking into consideration selective but relevant literary fabrications, the brainchilds of one of the two internationally recognized Naga Writers, Dr Easterine Kire with the other being Dr Temsula Ao.

Methodology: This write-up is built upon the selective reading of the summary of the novels and poems of both the writers with selective perusal of secondary anecdotage in the form of critical essays, the Naga History of Independence and Naga Anthropology.

\section{INTRODUCTION}

The Naga Identity is a very complex phenomenon the pivot of which is rooted in the Naga History dating back to British Rule. Rani Gaidinliu, the Rongmei Naga Spiritual and Political Leader who is widely known for her belief in and adherence to the Heraka Religious Practice challenged the American Baptist Missionaries outright mission of converting the Nagas. She believed that the traditional Naga Religious tenets comprising of head-hunting, heroworship and animism were rich enough to mould the genuine Naga Identity versus the baptized Naga Identity. Her armed guerrilla movement not only made her famous but at the same time surrendering to British Machiavellian machinations triggered her hibernation and fighting for existence from underground. However, when India became independent, the Government of Independent India saw to it that she lived a fresh life and that in turn prevailed upon her to profess that being assimilated into the Indian mainstream would rather advantage the greater population of Nagaland. In this aspect she highly dissented with the views of Naga National Council which have forever dreamt about an independent Nagaland. The latter seeing its hopes dashed through the skilful annexation of the Nagaland into the greater Indian Territory with the concession of autonomy sensed to be partially appealing is found to have played a key role in triggering the genesis of its armed wing National Socialist Council of Nagaland by the end of 1990s. The very genesis of the NSCN and different factions within the same, their periodical sealing of ceasefire agreements which is valid as of 2019 tacitly connotes the fact the Nagas will simply have been whiling away time, remaining inconclusive whether or not to fully integrate themselves into the greater Indian sense of Nationhood.

Both the writers namely Easterine Kire and Dr Temsula Ao have questioned the dynamics encompassing the genesis and flux of critical ideologies supporting this Naga resistance movement throwing insights into the validity and non-validity of this very movement.

The armed resistance by the Nagas through NSCN (K) and NSCN (I.M) has been synthesized into the literary fabric by both of these writers. But frankly speaking the poetics of Naga Identity encompasses more elements than these as evidenced by the literary outputs engineered by the duo. Issues of domineering patriarchal hegemony and its challenge to outright manifestation of liberal feministic existence championed by the Naga women with the validity of the latter being embedded in changing culturescape have been skilfully deliberated upon by the writers.

\section{DECRYPTING THE VERY POLITICS OF NAGA IDENTITY:}

Easterine Kire ( Dr. Easterine Kire , Professor of English , NEHU) has staunchly dealt with the Naga Conflict climaxing in 1960s and 1970s, the relative aftermaths of orchestrated but partially defeated secession, consolidation and genesis of the outright armed separatist movement, mobilized under three significant Naga separatist leaders namely Khaplang, Muivah and Tsu in her novel namely 'A Naga Village Remembered '(2003) , the writer has highlighted the ingrained resistant attitudinizations of the Nagas against the British Army, the latter being on a clandestine agenda of totally converting the hearaka religion practising Nagas into true born Christians as pointed out by Dr Kire. Kire has simultaneously also foregrounded the hegemonic British Agenda of totally mentally deculturing the Nagas, substantiating the invalidity of their traditional animism-inspired religious beliefs and implanting the behemoth European Colonial Culture to leverage the same cultural implant according to the latter's requirements. Using the postcolonial tool of analysis, Kire has established the incomparability of British regimeenforced Christianity to the traditionally abundant and enriched Naga religion founded on morungs and monoliths. It is often said that the writers Temsula Ao, Easterine Kire, Monalisa Changkija, Nini Lungalang, Avinuo Kire and 
others explore contemporary issues of their society and human predicament in its multiple dimensions, coupled with lyrical exuberance. [1]

Another rudimentary facet of Naga identity is undoubtedly embedded in dwelling upon and enumerating the role of women as conditioned by the patriarchal ideology inspired Naga Society and this has been well-displayed in the novel "A Terrible Matriarchy" (2007). Though Patriarchality is a domineering phenomenon, it in nowise tries to deny the extension of basic rights to women. The heroine 'Dielieno' has been very efficaciously delineated by the writer. And same is the case with her mother, grandmother all of whom are embodiments of the progressive mental upliftment of the conditions of women.

British Imperialism is another important rudiment going into formulating the Naga Poetics of Identity. When Nagalnd went under the British rule, multiple challenges cropped up. The novel in question is Mari (2010) wherein the protagonist is Mary O Leary. By 1944, Japan invaded Nagaland, causing the retreat of the British soldiers, thereby ushering in a deluge of exploitation, impoverishment, famine and in the aftermath justifying the undergoing of temporary Odyssey of the afflicted. The British lover of the Naga girl was not there to help her out, causing her and her family members to leave their homes, flitting through forest covers, eating wild food. This novel is frankly speaking a kind of tacit satirical delineation of the society bogged down by inhuman wars.

Easterine Kire's other prominent novel is 'Bitter Wormwood' (2011) into the fabric of which the long-pending and unsolved Naga political problem is interwoven. Naga political problem till date has reached the climactic cul-desac. As Jacques Derrida uses the term aporia (that which can't be transcended) in terms of semantics; so is the situation with the Naga Political problem, reaching the deadlock. The novel is an outright rejection of the militant ideology believed to bring about any solution apart from triggering poverty, slaying human sentimentalism. As for the plot of the story, it hovers around two soldiers fighting on two different sides, thereby perpetuating the dominance of traditional hostility in the ambience between the families the grandchildren of which are ultimately found to appreciate the futility of waging hostilities against each other. The attitude of the grandchildren to the august decision freezing the deadlock connotes the supremacy of forgiveness which starkly contrasts against the attitude of inveterately harbouring animosity-charged modus operandi. As for the title of the novel, the word 'bitter wormwood' refers to a herb often tucked by Nagas into their years to encounter and avert the noxious effects arising out of being stalked by evil spirits if by chance. What Easterine Kire has tried to foreground is that the 'bitter wormwood' has enough potential to circumvent the ill-effects of Naga Struggle for independence both under the British Indian Regime and afterwards under the Indian Regime. Thereby the author also insinuates that armed struggle is not a solution and frankly speaking till date it has only contributed to the loss of lives, achieving nothing for the Nagas. Imagery of gun battles, midnight ambushes and mindless aggression woven into the fabric of the novel simply betokens that Kire has aptly harnessed the pertinent aspects relating to the political struggle only to substantiate their grave role in worsening the prevalent socioscape.

Dinkypu (2012) is a graphic novel, exploiting the rudiments of magic realism and interweaving it with childlike fantasy with the female child protagonist Mally cementing an indelible bonding with a gatecrashing stranger Dinkypu, a wombat and in that process happens to be gifted with magical experiences when the parents of Dinkypu, turning out to be visiting the former. The novel can be termed a tacit endorsement of the fact that Naga myths and legends occupy an irreversible slot in the social psyche of the Naga community.

The Log-Drummer Boy (2013) is another graphic children novella hovering around the life of the protagonist Nokcha who once having been initiated into acculturing himself into playing the log-drum turns out to be the saviour of the village from enemies, thereby substantiating the validity of strictly adhering to the Naga traditions.

But what strikes the reader and torpedoes to the innermost recesses the vivacious psyche of the eternally conscious reader is the modus operandi of the description strategy adopted by the writer in foregrounding the treatment meted out to the Nagas in the mainstream culture. The novel in question is Different Strokes seeing the light of the day in 2013. As the title suggests, it is about the perception of the Naga Culture at the mainstream level. We are transported to a world where two youths struggle with the bullying enacted by the so-called mainstreamers simply because they appear different in terms of their sustained venture to cling to their rich culture.

Naga folklores, myths, and legend constitute a considerable part of Naga beliefs and credos and as such can be termed as an indispensable part of Naga cultural, social and literary consciousness. The novel 'When the River Sleeps' (2014) quite confidently and so-so artistically interweaves myths, legends and folklores into the very fabric of the novel, hovering around the life of the rustic boy 'Vile'. The novel talks about spirits, sorcerers, sorceress which are believed to have inhabited the hills, mountains, jungles and thereby are believed to have played a pivotal role in sculpting so-called rich Naga consciousness. This novel is one way an argument for sustained adherence to the rituals 
and beliefs of the Nagas, their reverence for the land, their close-knit communities and the rhythm of life lived in harmony with natural surroundings and this can be aptly termed as Magic Realism so abundantly found in the works of the Latin American writer Gabriel Garcia Marquez and that of Russian writer Vladimir Nabokov. [2]

Thoughts after Easter by Easterine Kire published in 2014 must be taken into account as it turns out to be poignant recounting of social, environmental, personal and spiritual dimensions pivoting with the writer's life being the central spindle. But here too, the genius reader can sense the smokescreen of the descriptions camouflaging the futility of the orchestrated efforts in seeking a permanent solution to the Naga Conflict. But it goes beyond that and Professor A.J. Sebastian rightly observes, "Like a Stream of Consciousness writer, Easterine Kire takes the readers through everything human, yet part of the Divine in the mystery of Easter. In the four sections of the book she takes us along with her as she reflects on various issues afflicting us, even as she offers solutions. Her stimulating reflections of world events are replete with truth, mystery, humour and irony of life"

The Dancing Village published in 2015 is another masterpiece from the stable of the philoprogenitive writer and should be rightly termed as a continuation of the sustained endeavour to foreground the rich Naga Culture. More than that it is a cultural manifesto, bringing home the writer to apperceive the conspicuity of having a catholic view of the consolidated Naga Culture encompassing the cultural, religious beliefs of Ao, Zeliang and other tribes as well. As for the story, it rotates around the life of Seven Year old Rongsen who loved to dance, bridges the inter-cultural divide and gets an entire Ao Naga village dance to the rhythm of a Zeliang Naga dance, leading the two tribes to embrace each other in a celebration of friendship. As said by a prominent Naga critic, The Dancing Village' has been written in a very extraordinary style by linking multiple tribes, bridging inter-cultural division and overcoming orthodox style of thinking [3]

The very continuation of the obsession to treat folklores and myths of Nagaland is evident in the successive novel after a gap of two years. The Novel 'Son of the Thundercloud' published in 2016 is an in-depth penetration into the richness of Naga folklores and myths. It is about the fulfilment of a prophecy which goes on to say that the son of the thundercloud will usher in deliverance along with his arrival into the village. Here the son is none other than 'Pele' who on his village being affected by famine happens to reach the village of weavers, inhabited especially by three sisters namely Kethonuo, Siedze, and Mesanuo. In this very novel, the protagonist is Rhalie who along with three sisters deliberate upon the varied issues plaguing the society but the novel though points out the evanescence of famine from the village, it more than that foregrounds mental famine. the Son of the thundercloud (2016) is not just a prophetic tale; the new Easterine Kire said it was more like a Christological tale. In it Rhalie, a boy born from a drop of rainwater, came to offer redemption by killing a spirit-tiger. Inhabitants of a barren land, a village of weavers witness the rebirth of life everywhere around them thanks to him [4]

It will be a total mendacity and erroneous ejaculation if one is audacious enough to comment that Naga representation can be complete without diverging into the realm of exploring romantic hue that can also characterize Naga representation. The representation in question is about the novel 'Don't run, my love'. Though from the title it appears to be a romantic one but it transcends the very realm by touching upon and desperately trying to explore the nuances in relationship in the greater Naga Society which is known to have endorsed the virtues of fidelity, commitment and the puissance to be rebarbative towards injudicious overtures often underlining the span of romantic relationships. To be precise, the novel talks about the romantic adventures of the young girl Atuonuo, living with the widowed mother Visuenuo and her delicate romantic itinerary in company of the young and vivacious hunter Kevi. Kevi the hunter always dreaming to be easily winning the heart of the simple rustic girl Atuonuo feels flabbergasted on having been rejected by the unsure and unsettled heroine, forcing the former to turn on the latter. The novel thereby encapsulates the eternally pulsating clichéd acceptance regarding the tribal Nagas that they feel easily disgruntled on finding their simple romantic overtures shattered and this in turn can really animalize them to such an extent that it escapes any extent of explication. As said by a critic, Don't Run, My Love, a short novel, is a departure from her previous literary ventures in as much as it takes us to the realm of Naga folklore in a way that none of her previous works did. [4] While the subject of $A$ Naga Village Remembered was a battle between the British forces and a Naga hamlet, $A$ Terrible Matriarchy was a domestic drama that highlighted the effect of the political on the personal. Mari, based on a true story, dealt with the Japanese invasion of Nagaland in 1944 while Bitter Wormwood, focused on the human cost of the politics that led to human rights infringement in Nagaland. As a whole In the end it is a story about the learnings from love and the importance of being as strong as the woods and hills and the spreading branches of the wood apple tree that guards the village where mother and daughter seek refuge. [5] 
'Sky is my father' (2018) can be said to be outsmarting the description evidenced in 'A Naga Village Remembered' (published in 2003). Like the latter one, a poignant description of the Angami community whose stronghold is the Khonoma Village, fighting to the extent the last drop of blood being present against the unjustified British occupation, this novel is also a solid venture on the part of the writer retrospecting upon the enriched Naga Culture and its strict denial to accommodate its facile assimilation into British Culture both in the form of showing repugnance to and in the form of waging a war against the Britishers. It is a historical novel, delving into the nittygritties of Naga History from 1832 to 1880 when the Angami warriors of Khonoma carried out rebelliously disruptive ambushes upon the recruitment-driving British forces, enrolling the former as bonded labourers. The novel delineates with a broad brush the characteristic Naga penchant for basking in the serenity of the hills and clouds and then elucidates the points of vulnerability, leading it to be apathetically overrun by the juggernaut of imperial British culture. The Angami warriors of Khonoma perceiving the immediate extinction of their trivial existence try out consolidation of the remaining Naga tribes to wage an indefatigable battle against the not-so-easily beleaguerable British Army. It is also functioning as pointer to the fact that the entire Naga tribe irrespective of their differences should come out together to fight their common enemies and thereby establishes the superiority of the traditional culture over the over-bearing western culture. The novel glorifies the social taboos, rituals and festivals, abundantly evident in the Naga society and the word sky as used in the title bespeaks the supremacy of their primordial gods, the worshipping of the same.

The very style and very material constitute the hub of the latest novel 'A Respectable Woman' (published in 2019) which too is again an account of the Naga experiences during World War II when the British-led allies ultimately triumphed, underscoring the futility of the long-waged war against the beleaguering British Administration. However, the novel nowise can be termed only delving into the Naga Conflict which has been actuated and accentuated by the post-war famine, poverty and loss through the mouth of the female protagonist. The protagonist rather having been acquainted with this history through her predecessor, rates it her august onus of passing the entire memory to her daughter (whose mother is the protagonist Khonuo. The daughter is Kevinuo who has been bequeathed the hereditary largesse in the form of anecdotes chronicling the trajectory of evolution right from neo-nascence to adolescence on the part of the mother witnessing the unfolding of multiple parameters of the Naga National Movement under her own eyes. This novel has been aptly termed as an extension of Kire's earlier works such as Sky is My Father, A Naga Village Remembered (2003), on the clash between the British and Nagas in the 19th century, and Mari (2011), set during the Japanese invasion of Kohima during World War II and the post-war years.

\section{CRITIQUING}

The analysis presented with utmost meticulosity so far will be undoubtedly acknowledged as having proven the tenet that NAGA Culture has its own intrinsic seredipidity and significance. As such there is sufficient justification to preserve the cultural ethos by embattling oneself against all agents intimidating the extirpation of the native traits. Easterine Kire's approach is fully a postcolonial response as she vouches for the recognition of her native Angami culture and beyond that the consolidated scape of the cultures of entire Naga Tribes with her fictional characters challenging time and again the hegemony of Imperialism spearheaded by the British under the pretext of development propaganda. Another angle often noticed is that of eco-criticism as all her fictitious brainchilds clamour for the preservation of the pristinity, eternity of the theological, religious beliefs based on the apotheosization of the natural elements. The characters of the writer are found loitering in the cradle of nature, imbibing the flavours of nature. Even there is found to be abundant exuberance of the sensitization that ecology and feminine consciousness bonding is irreversibly indestructible. And as above-mentioned, Magic Realism forever conditions the style of description attempted by Easterine Kire (Aralu).

\section{CONCLUDING REMARKS}

Easterine Kire(Aralu) is one of the two eponymous writers of Nagaland, studying the different issues impacting the Naga Consciousness from the time of its occupation by the British involved in battles with different Naga Clans from 1820s to the present day which has witnessed disillusionment with and disintegration of the Naga dreams longcherished relating to visualizing and sculpting a Free Naga Country, restoring the entire native Naga ethos. Frankly 
speaking, Dr Kire has been very ingenuous in presenting the Naga Identity Poetics and its constituent elements as described hitherto because she looks at the same through the neutral kaleidoscope. positioning herself as a transcendental writer living in Norway. Thus, she is audacious in speaking out the echt effusions of her heart that does not understand politicking in detailing perceptions of the author in relation to her native culture, its fight for existence, temporal resurrection and finally heart-rending disintegration. Her efforts in giving a bold limelight to Naga Identity Poetics have met qualified competition and collaboration in the works of the other eponymous writer Dr Temsula Ao. As said by an academician, Representations of women by writers from the North-East, like Indira Goswami, Arupa Patangia Kalita, Rita Choudhury, Mamang Dai, Easterine Kire, Temsula Ao, Anjum Hasan, Monalisa Chankija, etc. are celebratory and liberating. To a considerable extent, their writings map a social and historical space that is polyphonic and variegated. Their writings interrogate the canonical texts, elitist practices and heterosexist assumptions of culture. These women writers from the North-East have invariably dealt with the issues of oppression, subjugation, invisibility, silences, and gaps in the periphery. However, their writings also question a legacy of what are being "discarded," "de-valued," and "discredited" in the context of the North-East. [6] This really sums up the traditionally accepted view regarding Dr Easterine Kire.

\section{SOURCES OF FUNDING}

This research received no specific grant from any funding agency in the public, commercial, or not-for-profit sectors.

\section{CONFLICT OF INTEREST}

The author have declared that no competing interests exist.

\section{ACKNOWLEDGMENT}

None.

\section{REFERENCES}

[1] Sebastian Adb, Prof Fr.A.J.(2016): Critical Essays on Naga Poets and Fiction Writers, Zubaan Books, ISBN 97893-5258-465-9

[2] Mishra, Dr Tilottatma (2017): Rereading Myths and Reconstructing Identity in Easterine Iralu's When the River Sleeps, International Journal of English Language Literature in Humanities, Volume 5, ISSN 2321-7065

[3] Liezietshu, Dr Shurhozelle (2015): Critique of The Dancing Village

[4] Gomez, Louis. A (2018): Myth and Ethos in Three Novels of Easterine Kire

[5] Sengupta, Dr. Paromita (2018): Review of Don't Run My Love, Muse India, Issue 78, ISSN: 0975-1815

[6] Basu, Anjana (2018): Don't Run, My Love - A Novella by Easterine Kire in indianliterature.org

[7] Pathak, Dr.Namrata \& Gracy, L.K (2016):Women's Writing From Northeast India, M.R.B. Publishers ,Delhi, ISBN-13: 978-9383403110

\section{WEBLIOGRAPHY}

[1] easternmorningherald.com

[2] nagalandmirror.com

[3] cafedissensus.com

[4] morungexpress.com

[5] reviewne.com

[6] indianculturalforum.in

[7] www.speakingtree.in 